\title{
Contribution to the feeding ecology of the banded puffer fish Colomesus psittacus (Tetraodontidae) in north Brazilian mangrove creeks
}

\author{
Krumme, $U .^{\mathrm{a} *}$, Keuthen, $H .^{\mathrm{b}}$, Saint-Paul, $U .^{\mathrm{a}}$ and Villwock, $W^{\mathrm{b}}$ \\ ${ }^{a}$ Center for Tropical Marine Ecology, ZMT, Fahrenheitstr. 6, 28359 Bremen, Germany

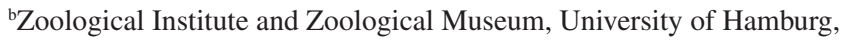 \\ Martin-Luther-King-Platz 3, 20146 Hamburg, Germany \\ *e-mail: uwe.krumme@zmt-bremen.de
}

Received April 11, 2005 - Accepted July 22, 2006 - Distributed August 31, 2007

(With 4 figures)

\begin{abstract}
Stomach contents were examined from 102 banded puffer, Colomesus psittacus (Tetraodontidae), caught from intertidal mangrove creeks at diurnal neap tides between June and September, 1997 (early dry season) near Bragança (north Brazil). The study found that C. psittacus were specialized predators of Cirripedia (Balanus spp.) and Brachyuran crabs (Uca spp., Pachygrapsus gracilis) (mean: 58 and 38\% by dry weight, respectively), emphasizing a short food chain in the mangrove system. Cirripedia and Brachyura dominated the diet in all size classes, however, the prey spectrum narrowed with fish size. The mean daily consumption of Cirripedia and Brachyura was $6.2 \%$ body weight of C. psittacus. On average C. psittacus consumed $100.3 \mathrm{~g} \cdot \mathrm{ha}^{-1} \cdot \mathrm{d}^{-1}$ of Cirripedia and $178.7 \mathrm{~g} \cdot \mathrm{ha}^{-1} \cdot \mathrm{d}^{-1}$ of Brachyura (wet weight). The predation on Brachyuran crabs - a significant driver of fluxes of organic matter and energy in the system - provides C. psittacus with an important ecological function in the mangrove food web. A plant-animal interaction is proposed where $C$. psittacus exerts a mutually beneficial cleaning function on the Aufwuchs (Cirripedia and associated epibiota) of Rhizophora mangle stilt roots. Our results and those of other studies suggest that $C$. psittacus encounter optimum foraging conditions in the mangrove at high inundations at daylight (spring tide-day) whereas darkness and low inundations are linked to poor foraging conditions (neap tide-night). The C. psittacus resource could be used as an alternative income in the region in terms of i) sustainable catch and filet processing for exports to East Asia, ii) developing certified aquaculture methods for breeding puffers for the aquarium trade.
\end{abstract}

Keywords: Brachyura, Cirripedia, fish diets, ontogeny, plant-animal interaction.

\section{Contribuição à ecologia alimentar do baiacu Colomesus psittacus (Tetraodontidae) em canais de maré com vegetação de mangue no norte do Brasil}

\begin{abstract}
Resumo
Conteúdos estomacais de 102 baiacus Colomesus psittacus (Tetraodontidae) foram examinados. A amostragem foi realizada em canais de maré com vegetação de mangue, durante as marés de quadratura de dia, entre junho e setembro de 1997 (no início do período seco), nas proximidades de Bragança (norte do Brasil). O estudo constatou que C. psittacus era um predador especializado em Cirripedia (Balanus spp.) e Brachyura (Uca spp., Pachygrapsus gracilis), com médias de 58 e $38 \%$ em peso seco, respectivamente, caracterizando uma curta cadeia alimentar no sistema de manguezal. Cirripedia e Brachyura dominaram a dieta em todos os tamanhos, entretanto, o espectro alimentar diminuiu de acordo com o tamanho do peixe. O consumo diário médio de Cirripedia e Brachyura foi de $6,2 \%$ em peso corporal de $C$. psittacus. $C$. psittacus consumiu uma média de 100,3 g.ha-1 $\cdot \mathrm{d}^{-1}$ de Cirripedia e 178,7 g.ha ${ }^{-1} \cdot \mathrm{d}^{-1}$ de Brachyura (peso úmido). A intensa predação de Brachyura por $C$. psittacus enfatiza a importante função ecológica desta espécie na cadeia alimentar do manguezal, contribuindo significativamente no fluxo de matéria orgânica. Uma interação planta-animal é indicada no fato que $C$. psittacus exerce uma função limpadora mutuamente beneficiável ao se alimentar do Aufwuchs (Cirripedia e epibiota asociada) que cresce nas raízes aéreas de Rhizophora mangle. Nossos resultados e os de outros estudos sugerem que $C$. psittacus encontra no manguezal as melhores condições para se alimentar no período diurno durante as maiores inundações (marés de sizigia - de dia), enquanto que períodos noturnos e de pequenas inundações determinam as piores condições para forragear (maré de quadratura - de noite). C. psittacus poderia ser usado como alternativa de renda na região com respeito a: i) pesca sustentável e processamento de filés para exportação ao leste da Ásia, ii) desenvolvimento de métodos de aqüicultura certificada para a criação de baiacu para o comércio de peixes ornamentais.
\end{abstract}

Palavras-chave: Brachyura, Cirripedia, dieta de peixes, ontogenia, interação planta-animal. 


\section{Introduction}

In the western Pacific, tetraodontids are commercially valuable and highly regarded as fish food, even though the presence of the family-specific tetraodoxin still causes the death of gastronomers each year (Fiedler, 1991). Furthermore, there is an increasing demand for tetraodontids in the aquarium trade. Although tetraodontids are used commercially, basic ecological knowledge of natural populations is usually scarce.

In tropical and subtropical mangroves, tetraodontids are often amongst the most common fish species sampled (Bell et al., 1984; Hindell and Jenkins, 2004). The banded puffer Colomesus psittacus (Bloch and Schneider, 1801 ) is distributed along the coast from east Venezuela to north Brazil but also occurs in freshwater, e.g. several $100 \mathrm{~km}$ upstream in the Amazon and its tributary river systems (Barthem, 1985; Cervigon et al., 1992). In freshwater, C. psittacus is carnivorous, feeding mainly on mollusks (Keith et al., 2000) but little is known about marine environments.

In mangroves along the north Brazilian coast C. psittacus is one of the dominant fish species of tidal channels year-round (Castro, 2001; Barletta et al., 2003; Krumme, 2004; Krumme et al., 2004). The intestines of tidally migrating $C$. psittacus were empty at flood tide and well-filled at ebb tide when the fish returned from the intertidal zone (Krumme, 2004). C. psittacus is usually the only tretraodontid species in these mangroves. Juvenile Spheroides testudineus occur as accidental visitors.

The toxicity of pufferfish is well-known among fishermen and only very few seem to have really ever eaten puffer filet (pers. comm. with fishermen). Therefore, C. psittacus is usually discarded from the semi-commercial tapagem and curral catches (Barletta et al., 1998) and is of no commercial importance and not marketed.

Puffers have three defense mechanisms against predators: being poisonous, inflation (with water or air) and aposematism (dorsal transverse black bars as warning coloration; Krebs and Davies, 1993). Puffers have a beak-like, terminal mouth with a bony plate in both jaws that can crush hard-shelled organisms. In mangroves, these adaptations enable them to prey on the ubiquitous fiddler crabs, which are unapproachable by many other fish species. Given the important functional role that these crabs have, puffers may have a significant impact on the ecological functioning of the system.

So far, detailed quantitative assessment of the food habits of $C$. psittacus, including the effect of ontogeny, is lacking and its ecological role in the mangroves is still unknown. Trophic modeling relies on a predatorprey matrix and the consumption per unit of biomass (e.g. Wolff et al., 2000). Therefore, the objectives of this study were to describe the diet of mangrove-dwelling C. psittacus quantitatively and determine ontogenetic patterns in their diet.

\section{Materials and Methods}

\subsection{Study area}

The study area is located in the Caeté River estuary near Bragança, about $200 \mathrm{~km}$ south-east of the Amazon delta. It is part of the second largest mangrove area of the world, covering about 7,000 $\mathrm{km}^{2}$ on the north-east coast of South America (Kjerfve and Lacerda, 1993). Vast forests of Rhizophora mangle and Avicennia germinans dominate the coastal vegetation in the region.

The sample sites were three intertidal $1^{\text {st }}$ order mangrove creeks in the muddy upper reaches of the Furo do Meio, located in the central part of the peninsula bordering the western side of the Caeté bay (see Figure 1 in Barletta-Bergan et al., 2002). Approximately $110 \mathrm{~km}^{2}$ of the peninsula are covered by mangrove. In the Caeté estuary, intertidal 1st order creeks (about $25 \mathrm{~m}$ width at the mouth) that are further ramified upstream, drain the mangrove area into a large subtidal main channel ("Furo", $50 \mathrm{~m}$ width and larger) that are connected to the Caeté bay. According to Barletta-Bergan (1999), creeks 1, 2 and 3 had $6,481,9,351$ and $1,865 \mathrm{~m}^{2}$ of inundated areas at neap tide high water (HW), respectively. The vegetation of the studied creeks is dominated by $R$. mangle and $A$. germinans and can therefore be considered representative for a large part of the mangrove area.

The semidiurnal macrotide has a tidal range of 2-3 m at neap and 3-4 $\mathrm{m}$ at spring tides. The tide is asymmetric; the flood and ebb tides last 4 and 8 hours, respectively. In the last 4 hours, the ebb tide is extremely weak with an almost negligible fall in the water level. The annual average rainfall is about $2,500 \mathrm{~mm}$, with a significant dry season between August and November when estuarine salinities can exceed $35 \mathrm{psu}$. The air and water temperatures are high year-round, ranging from 25 to $33^{\circ} \mathrm{C}$ and 27 to $30^{\circ} \mathrm{C}$, respectively. The secchi depth is usually low (on average $30 \mathrm{~cm}$ ).

\subsection{Sampling method}

C. psittacus were caught for stomach analysis during diurnal neap ebb tides of the last quarter moon. Samples were taken monthly between June and September 1997 (early dry season) as part of the one-year study of Barletta et al. (2003) and Barletta-Bergan et al. (2002). The three creeks were sampled on consecutive days. Each day at slack HW, a creek mouth was blocked with a net $(50 \times 5 \mathrm{~m}, 1 \mathrm{~cm}$ stretched mesh size). Fish were collected during the ebb tide until the creek was totally drained (ca. six hours after HW). In the field, specimens were directly fixed in $15 \%$ borax-buffered formalin in sea water. Salinity increased from 22 to $24.7,28.7$ and 31.5 psu between June and September, respectively.

\subsection{Morphometrics}

The total length (TL), standard length (SL) (both to the lowest $0.5 \mathrm{~cm}$ ), total wet weight and wet weight without stomachs were taken (Sartorius LC $4200 \mathrm{~S} \pm 0.01 \mathrm{~g}$ ). The length-weight relationship ( $\left.\mathrm{W}=\mathrm{a} \times \mathrm{L}^{\mathrm{b}}\right)$ of C. psittacus was determined, using $\mathrm{n}=122,417$ and 260 


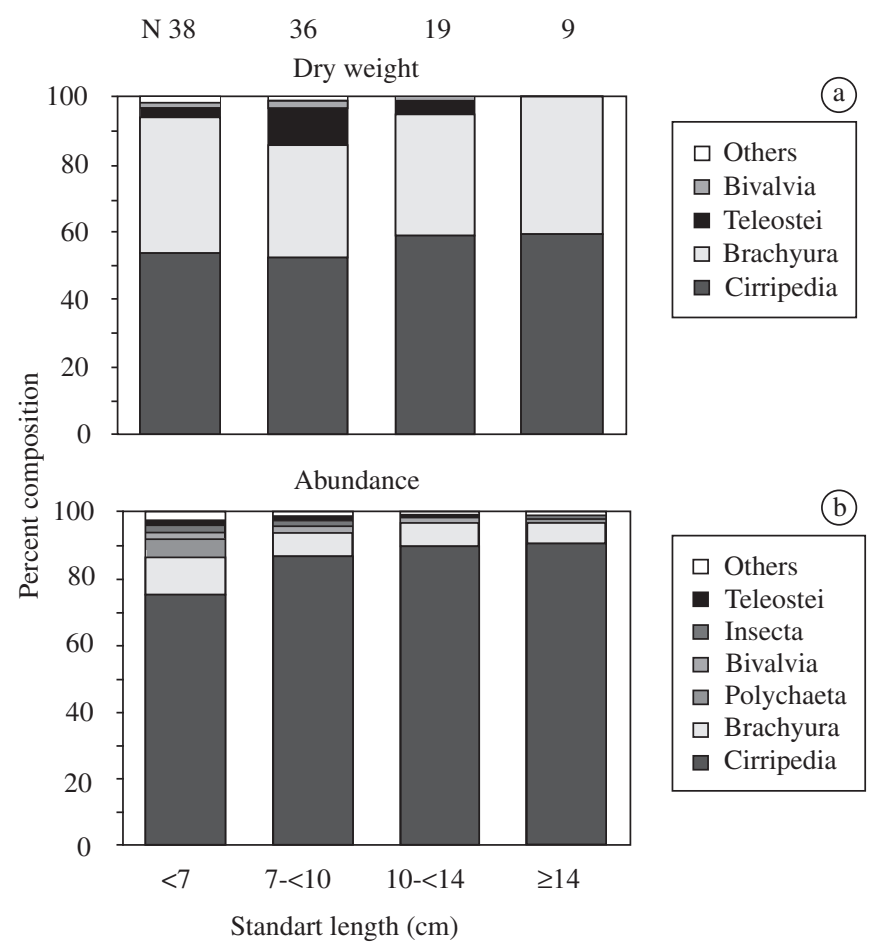

Figure 1. Ontogenetic changes in diet composition of C. psittacus from intertidal mangrove creeks (north Brazil) caught at diurnal neap tides in the early dry season of 1997 . Histogram for each size class shows relative proportions of a) percent dry weight and; b) percent abundance of the food items. Number collected per size class $(\mathrm{N})$ is given on top.

specimens from the present study, from Krumme et al. (2004) and of samples taken in the Furo do Meio in the dry season 2002, respectively. The parameters $a$ [W in gram; L in cm TL (Xiao, 1998)] and $b$, and the condition factor c.f. $\left[\right.$ c.f. $\left.=\left(\left(\sum(\mathrm{W} \times 100) \times\left(\mathrm{L}^{-3}\right)\right) \times \mathrm{n}^{-1}\right)\right]$ were calculated (Cinco, 1982).

The length of the uncoiled digestive tract (DT) was measured from the pylorus to the anus $( \pm 0.5 \mathrm{~cm})$. The relative length of the DT (RLDT) was calculated (DT length $\times \mathrm{TL}^{-1}$ ). The feeding habit was classified according to Odum (1970) who suggested a relative GIT length of $<1,1-3$ and $>3$ for carnivorous, omnivorous and herbivorous fish, respectively.

\subsection{Stomach fullness}

All but three stomachs were empty. 'Puffers have an inflatable abdominal sac, a ventral diverticulum continuous with the stomach' (Targett, 1978). C. psittacus inflated when captured and could thus have drawn extraneous material into the stomach (Targett, 1978). 'Puffer stomachs have poorly developed digestive glands with most digestion taking place in the intestine' (Breder and Clark, 1947). Therefore, only the intestinal contents were analyzed. The intestines were transferred to $8 \%$ buffered formalin, washed, drained on absorbent paper and wetweighed $( \pm 0.01 \mathrm{~g})$. The weight of the contents of the intestines $(\mathrm{C})$ was calculated as $\mathrm{C}=\mathrm{R}-\mathrm{E}$; where $\mathrm{R}$ is the weight of the removed intestines $(\mathrm{g})$; $\mathrm{E}$ is the weight of the empty intestine $(\mathrm{g})$. Intestines were opened and in- testine fullness was assigned to five categories, adapted from Pillay (1953): empty; filled to $25 \%$; filled $>25-50 \%$; filled $>50-75 \%$; filled $>75-100 \%$ full. Alternatively, the intestine fullness index (IFI) following Hureau (1970) was calculated as IFI $=(($ intestine content weight $\times 100)$ $x$ total fish weight $\left.{ }^{-1}\right)$. The fish were assigned to four size classes: $<7 \mathrm{~cm} ; 7-<10 \mathrm{~cm} ; 10-<14 \mathrm{~cm} ; \geq 14 \mathrm{~cm}$ SL.

A three-way analysis of variance (ANOVA) type II was calculated to ascertain whether IFI differed by month, size class and creek (Sokal and Rohlf, 1995). The creek was the unplanned factor. The IFI raw data were $\log 10(\mathrm{x}+1)$-transformed to fulfil the ANOVA assumptions. To avoid an incomplete design, the two largest size classes and the months June/July and August/September were pooled.

\subsection{Stomach content analysis}

Intestine contents were washed in distilled water to substitute formol before the contents were observed under a ZEISS-STEMI SV-11 stereo magnifying glass or microscope and separated into prey categories (e.g. Cirripedia, Brachyura) while prey items were identified as precisely as possible according to the literature (Kaestner, 1963; Chace and Hobbs 1969; Riedl, 1970; Abbott, 1974; Rodriguez, 1980; Laguna, 1985; Cervigon et al., 1992; D'Incao, 1995; Hayward and Ryland, 1995). Most prey items, unless very small, are broken once they reach the intestine. Therefore, unique body parts of the prey items were identified and counted, e.g. entire bod- 
ies of barnacles, crab eyes or bivalve shells with hinge teeth. The items of each category were counted and transferred to $4 \%$ formalin. After freeze-drying, the dry weight of the categories was taken (Sartorius Analytica $200 \mathrm{a}, \pm 0.0001 \mathrm{~g})$.

\subsection{Standardization of content weights}

The effect of fish size within the different size classes was accounted for by standardizing intestine content weights to the geometrical mean weight of all investigated fish of a single size class according to Brenner et al. (2001). A linear regression between the fish weight (FW) and weight of the empty intestine (E) was established:

$\mathrm{E}=\mathrm{a}+\mathrm{b} \times \mathrm{WF}$

Subsequently, number $\left(\mathrm{NP}_{\mathrm{j}, \mathrm{i}}\right)$ and weight $\left(\mathrm{WP}{ }_{\mathrm{j}, \mathrm{i}}\right)$ of each prey item $j$ found in the intestine of a fish $i$ of weight $\mathrm{WF}_{\mathrm{i}}$ was standardized (SF). Standardization used the geometrical mean weight $(\mathrm{GM})$ for the size class where the fish $\mathrm{WF}_{\mathrm{i}}$ was stated as:

$$
\begin{aligned}
& \mathrm{WP}(\mathrm{SF})_{\mathrm{j}, \mathrm{i}}=\left(\mathrm{WP}_{\mathrm{j}, \mathrm{I}} \times(\mathrm{a}+\mathrm{b} \times \mathrm{GM})\right) \mathrm{x} \\
& \left(\mathrm{a}+\mathrm{b} \times \mathrm{WF}_{\mathrm{i}}\right)^{-1}
\end{aligned}
$$

Using $\mathrm{y}=0.025 \mathrm{x}-0.016\left(\mathrm{r}^{2}=0.95 ; \mathrm{n}=101\right)$ we converted the original stomach content weights into standardized stomach content weights for each size class (Brenner et al., 2001).

\subsection{Patterns in diet composition and feeding strategy}

The similarities in diet composition between size class and month were displayed using non-parametric multidimensional scaling (MDS) (Clarke and Warwick, 1994). In the original species-sample table, each cell contained the standardized mean weight of food item $(\mathrm{g})$ per size class and month (e.g. Jun1 = smallest size class in June). We used square-root transformation to generate the BrayCurtis similarity matrix. The stress of the MDS representation - a measure of how well the ordination represents the similarities between the samples - was assessed using the classification of Clarke and Warwick (1994) where a stress value $<0.1$ corresponds to a good ordination with no real prospect of a misleading interpretation.

The feeding strategy of $C$. psittacus was assessed using the feeding strategy plot of Costello (1990). The prey-specific abundance was based on dry weight.

\subsection{Index of predation impact}

An index of predation impact was measured as the weight of the prey (Cirripedia or Brachyura) eaten by $C$. psittacus per hectare and day. The index was calculated according to Brewer et al. (1991) and Salini et al. (1998) as the product of predator biomass per tide $\left(\mathrm{g}^{\mathrm{h}} \mathrm{ha}^{-1}\right)$, the mean proportion of prey in the diet per tide and a factor 2 to account for the semidiurnal tide. We used the sum of the submerged surface area of the three creeks that Barletta-Bergan (1999) estimated for a common neap tide inundation $\left(17688 \mathrm{~m}^{2}\right)$ to calculate the surface relationship in the predator biomass. Neap tide inundations are restricted to the network of creeks and therefore, surface area measurements taken once at slack neap high tide can be used as a coarse approximation for the general neap tide inundation area, despite variability in the submerged area between tides (Krumme et al., 2004). We do not provide a conventional evacuation measure. Krumme (2004) found a significant difference between empty flood and well-filled ebb tide intestines of tidally migrating $C$. psittacus at diurnal neap tides in the study area. Hence, we assume that the stomach contents at the end of the ebb tide are the minimum of what the fish have eaten, thus it is a conservative measure. Factor 2 assumes that each intertidal inundation, both in the daytime and at night, is a feeding period for $C$. psittacus while the low water period is not. The dry weight proportion of the prey in each individual predator intestine was used to assess the wet weight proportion and was multiplied by the individual predator wet weight and monthly averages were calculated.

\section{Results}

We caught 28, 24, 25 and 25 C. psittacus in June, July, August, and September, respectively, which were used for quantitative assessments of feeding habits ( $n=102$; size range: $4-20.5 \mathrm{~cm} \mathrm{SL}$ ). $73 \%$ of the intestines were more than $50 \%$ filled. There was no empty intestine and only $6 \%$ were filled to less than $25 \%$.

Morphometric relationships of $C$. psittacus are shown in Table 1. C. psittacus displayed a slightly negative weight increase $(b<3)$. The condition factor was 3.2. The intestine lies in the posterior section of the abdominal cavity where it forms two or three loops. The mean RLDT (1.0 $\pm 0.2 \mathrm{SD}$; range: $0.7-1.4 ; \mathrm{n}=56)$ indicated a carnivorous feeding habit of $C$. psittacus.

Table 1. Length relationships of $C$. psittacus from mangrove creeks near Bragança, north Brazil. $\mathrm{N}$ is the sample size; $\mathrm{r}^{2}$ is the coefficient of determination.

\begin{tabular}{lllrrr}
\hline \multicolumn{1}{c}{ Relationship } & \multicolumn{1}{c}{ Formula } & \multicolumn{1}{c}{ Variables } & Size range & N & $\mathbf{r}^{2}$ \\
\hline Length-weight & $\mathrm{Y}=0.059 \mathrm{X}^{2.7}$ & $\mathrm{Y}=$ Weight $(\mathrm{g}) ; \mathrm{X}=\mathrm{TL}$ & 1-31 cm TL & 799 & 0.99 \\
Length-length & $\mathrm{Y}=0.834 \mathrm{X}-0.315$ & $\mathrm{Y}=\mathrm{TL} ; \mathrm{X}=\mathrm{SL}$ & 4-20.5 cm SL & 105 & 0.99 \\
Length-length & $\mathrm{Y}=1.192 \mathrm{X}+0.443$ & $\mathrm{Y}=\mathrm{SL} ; \mathrm{X}=\mathrm{TL}$ & 5-25 cm TL & 105 & 0.99 \\
Stomach length & $\mathrm{Y}=0.886 \mathrm{X}+1.365$ & $\mathrm{Y}=$ stomach length; X = TL & 5-25 cm TL & 56 & 0.84 \\
\hline
\end{tabular}




\subsection{Stomach fullness}

IFI was significantly higher in the two larger creeks 1 and 2 than in the small creek 3 (three-way ANOVA, $\mathrm{F}=12.68, \mathrm{P}<0.001)$. The IFI was significantly higher in June/July than in August/September (three-way ANOVA, $\mathrm{F}=68.65, \mathrm{P}<0.05)$. Although the IFI did not differ between size classes, there was a trend to decreasing IFI with increasing fish size. On average, the fish had eaten $7 \% \pm 3.3 \mathrm{SD}$ of their wet weight $(\mathrm{n}=102$; range: $0.4-15.4 \%)$.

\subsection{Diet composition}

Cirripedia (Balanus amphitrite, B. eburneus, and probably some other species) and Brachyuran mangrove crabs dominated the diet with on average 58 and $38 \%$ of the dry weight, respectively (Figure 1). Uca spp. and Pachygrapsus gracilis were the most abundant Brachyuran crabs in the diet (Table 2). Other important food items in terms of weight were Teleostei (usually only muscle tissue and scales) and Bivalvia (Mytella strigata, M. guyanensis, Crassostrea aff. rizophorae). Less important were Polychaeta (Isolda aff. pulchella, Nereididae, Capitellidae, Phyllodocidae), insects (Blattodea, Hemiptera, Diptera, Hymenoptera), filamentous red and green algae (lacking any indication of digestion), Gnathiidae (praniza stage), Natantia (Troglocubanus sp.), Gastropoda (c.f. Littorina angulifera), Amphipoda (Corophioidae), Bryozoa (Membraniporidae), Mysidace a, and seeds. The number of prey categories decreased with increasing fish size $(14,12,8$ and 6 prey categories from the smallest to the largest size class) (Figure 1). Only the largest size class had no Teleostei in the intestines.

Cirripedia dominated the diet in June/July (77 and $83 \%$ of the total dry weight, respectively) but decreased in August (43\%) down to 16\% in September. Contrarily, Brachyura were less important in June/July (14 and 15\% respectively), but increased in August (51\%) and dominated the diet in September (79\%) (Figure 2). The other food items were too rare to detect a temporal trend.

Table 2. Relative abundance of taxa within the food category "Brachyura" of $\mathrm{n}=102$ C. psittacus from intertidal mangrove creeks in north Brazil, June-September 1997.

\begin{tabular}{lr}
\hline \multicolumn{1}{c}{ Brachyuran crab species } & \% \\
\hline Uca spp. (Ocypodidae) $^{\mathrm{a}}$ & 41 \\
Pachygrapsus gracilis (Grapsidae) & 14 \\
Aratus pisonii (Grapsidae) & 8 \\
Xanthidae & 7 \\
Sesarma sp. (Grapsidae) ${ }^{\mathrm{b}}$ & 4 \\
Goniopsis cruentata $($ Grapsidae) & 1 \\
Callinectes sp. (Portunidae) & 1 \\
Unidentified & 22 \\
\hline
\end{tabular}

${ }^{\mathrm{a}} U$. cumulanta, U. maracoani, $U$. vocator; and ${ }^{\mathrm{b}} S$. rectum, S. curacaoense
Classification of the diet composition of C. psittacus showed that the grouping patterns were primarily determined by changes in the proportions between Cirripedia and Brachyura (Figure 3). Ordination by non-metric multidimensional scaling (MDS) revealed a "horizontal Cirripedia axis" and a "vertical Brachyura axis": These samples without or poor in Cirripedia, mainly taken in August and September (left group), were separated from samples containing Cirripedia, mainly taken in June and July (right group). Samples with the highest proportions of Brachyura coinciding with the largest size classes in August and September were located at the bottom (see also Figure 2).

The feeding plot in Figure 4 shows that $C$. psittacus is a specialized feeder of Cirripedia and Brachyura. Cirripedia and Brachyura were found in 50 and $85 \%$ of

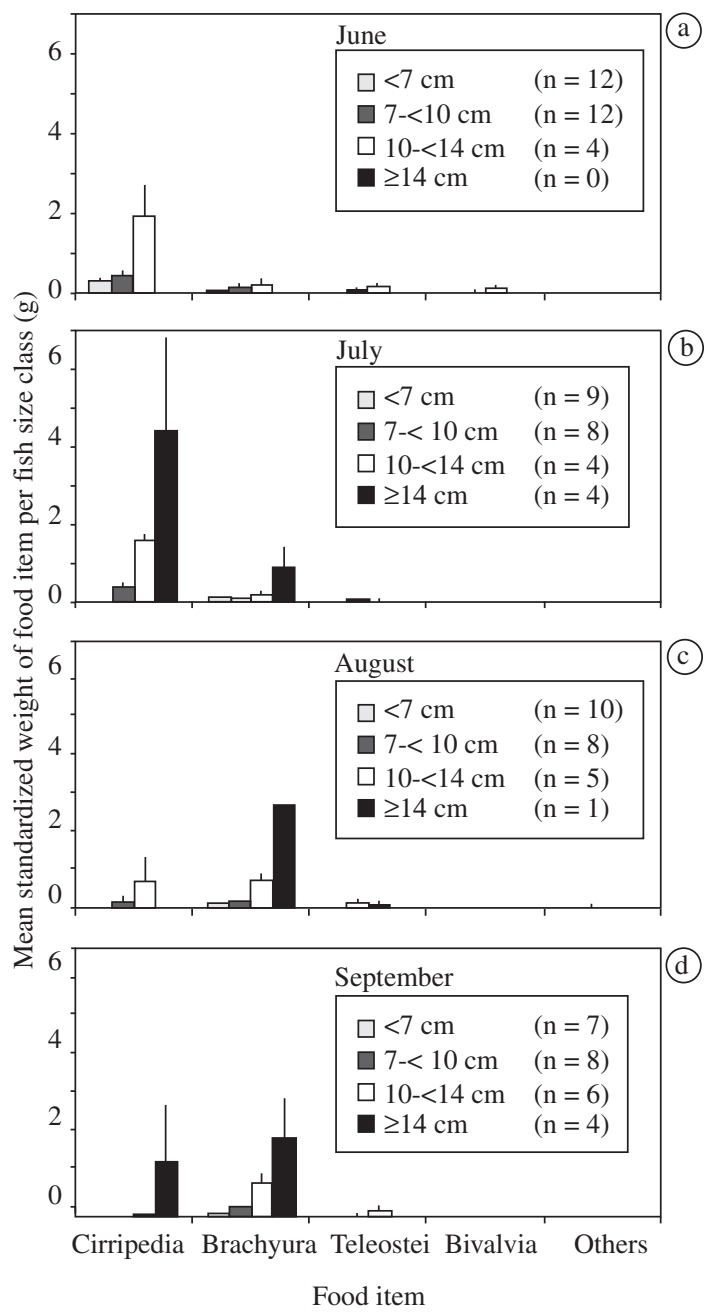

Figure 2. Food composition in monthly samples (June September) of four size classes of $C$. psittacus in grams dry weight $( \pm \mathrm{SD})$. Dry weights of food items were standardized per fish size class. Specimens were caught in three intertidal 1st order mangrove creeks of the Furo do Meio (north Brazil) at diurnal neap tides in the early dry season of 1997. 


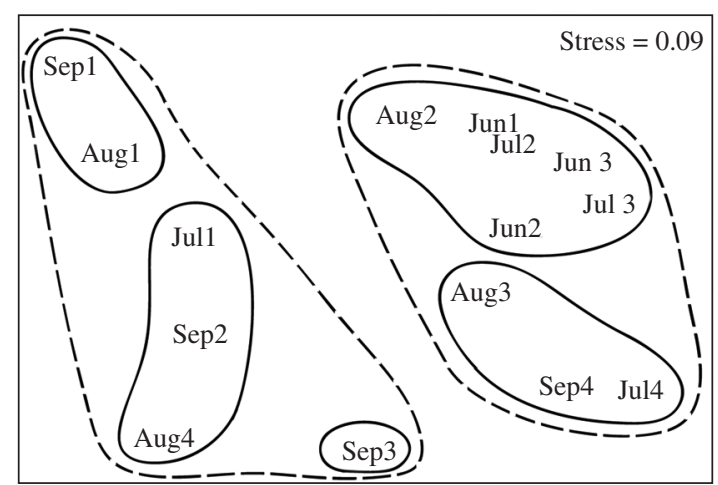

Figure 3. MDS plot of the similarities in food composition of $C$. psittacus caught at high water at diurnal neap tides in 1st order mangrove creeks of the Furo do Meio (north Brazil) in four months in the early dry season 1997. Identification codes indicate month of capture and size class $(1:<7 \mathrm{~cm} \mathrm{SL}$; 2: $7-<10 \mathrm{~cm} ; 3: 10-<14 \mathrm{~cm} ; 4: \geq 14 \mathrm{~cm})$. Groups are circled according to $53 \%$ (dashed line) and $63 \%$ (continuous line) similarity of the cluster dendrogram (not shown).

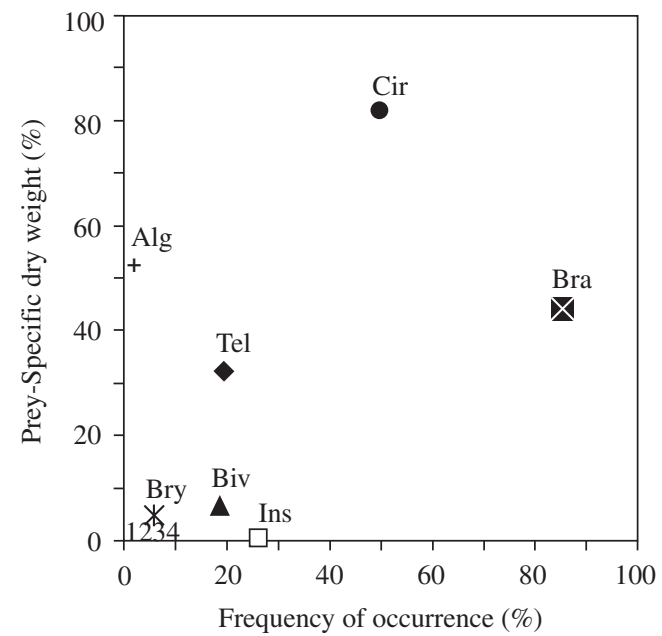

Figure 4. Feeding strategy plot (Costello 1990) based on prey-specific dry weight of $C$. psittacus $(\mathrm{n}=102)$ caught in the mangrove channel Furo do Meio (north Brazil) in the early dry season 1997 . The points represent the food items Bra: Brachyura; Cir: Cirripedia; Tel: Teleostei (artefact in the diet); Alg: Red and green algae; Bry: Bryozoa; Biv: Bivalvia; Ins: Insecta; 1: Gastropoda; 2: Amphipoda; 3: Natantia 4: Polychaeta.

the intestines, respectively, and the average contribution to the intestine weight was 82 and $44 \%$, respectively. Teleostei were only consumed by $20 \%$ of the C.psittacus but contributed $32 \%$ to the intestine weight. Two specimens consumed considerable amounts of algae. There was neither a high within- nor between phenotype component, thus indicating a relatively narrow feeding niche. The other prey categories were occasionally included in the diet of some individuals, but had an insignificant contribution to the intestine weight.

\subsection{Predation impact}

The measure of predation impact on Cirripedia and Brachyura is shown in Table 3. Monthly changes in the predation impact reflect the monthly differences in food consumption (Figures 2, 3). On average $100.27 \mathrm{~g} \cdot \mathrm{ha}^{-1} \cdot \mathrm{d}^{-1}$ Cirripedia and $178.66 \mathrm{~g} \cdot \mathrm{ha}^{-1} \cdot \mathrm{d}^{-1}$ Brachyura (wet weight) were eaten by $C$. psittacus during the sample period. The mean daily consumption of Cirripedia and Brachyura was $6.2 \%$ per body weight of C. psittacus.

\section{Discussion}

This study provides first hand information on the feeding ecology of mangrove-inhabiting C. psittacus. A general shortcoming of our study is the limited sample period and the low sample sizes in some month-size class combinations. Nevertheless, some general patterns emerged that contribute to our understanding of the feeding ecology of. C. psittacus.

\subsection{Food composition}

Cirripedia and Brachyura dominated the diet in all size classes. An ontogentic feeding shift in C. psittacus was only apparent in terms of narrowing the prey spectrum with size. The weight proportion of the wider range of prey items in the smallest size class was too small to be translated quantitatively. In contrast, Targett (1978) found both qualitative and quantitative changes with growth in the diets of $S$. spengleri and S. testudineus. The lack of a significant quantitative change in the food habit of $C$. psittacus may reflect the overall abundance and availability of Brachyura and Cirripedia and the minor abundance of bivalves or gastropods in appropriate size ranges in the macrotidal Caeté estuary (Wolff et al., 2000). The considerable amount of hard-shelled items in the diet may explain the relatively long RLDT of C. psittacus. According to Al-Hussaini (1947) mollusk feeders have RLDT between 0.6 and 1.4.

Several examples of similar diet spectra have been observed for the Tetraodontidae family. The diet of the milk-spotted puffer Chelonodon patoca near Townsville (Australia) (Beumer, 1978) and of the puffers S. spengleri and S. testudineus (Targett, 1978) in Florida are also dominated by hard-shelled crustaceans and mollusks. However, Cirripedia and Brachyura are less dominant while other food items such as copepods or hermit crabs occurred more frequently. S. rosenblatti prey upon mangrove periwinkles up to $13 \mathrm{~cm}$ above the water surface in Puerto Rico (Duncan and Szelistowski, 1998). S. spengleri breaks the shells of gastropods and only swallowed the soft portions (Targett, 1978). The few gastropods in the diet of $C$. psittacus were consumed including the shell suggesting that gastropods are too rare to induce a specialization in prey handling.

The gradual replacement of Cirripedia by Brachyuran crabs between June and September in the diet of C. psittacus paralleled the gradual monthly salinity increase. Unpublished data of Giarrizzo suggest that the wet season diet of C. psittacus is dominated 
Table 3. Predation impact on Cirripedia and Brachyuran crabs by $C$. psittacus expressed in grams of prey wet-weight eaten per hectare per day. Fish were caught at diurnal neap ebb tides in intertidal mangrove creeks (north Brazil) with block nets in the early dry season 1997 . The predation impact is the product of the abundance of $C$. psittacus $\left(\mathrm{g}^{-h a^{-1}} \cdot \mathrm{tide}^{-1}\right)$, the mean proportion of Cirripedia or Brachyura in the diet per tide and multiplied by 2 to account for the semidiurnal tide. Daily consumption of Cirripedia and Brachyura is given in \% body weight of C. psittacus.

\begin{tabular}{|c|c|c|c|c|c|c|}
\hline \multirow[t]{2}{*}{ Month } & \multirow{2}{*}{$\begin{array}{c}\text { Predator } \\
\text { abundance } \\
\left(\text { g.hat }^{-1} \cdot \text { tide }^{-1}\right)\end{array}$} & \multicolumn{2}{|c|}{ Cirripedia } & \multicolumn{2}{|c|}{ Brachyura } & \multirow{2}{*}{$\begin{array}{l}\text { Consumption } \\
\left(\% \text { BW.d }^{-1}\right)\end{array}$} \\
\hline & & $\begin{array}{l}\text { Proportion in } \\
\text { the diet tide }\end{array}$ & $\begin{array}{l}\text { Predation } \\
\left(\text { g.ha }^{-1} \cdot d^{-1}\right)\end{array}$ & $\begin{array}{l}\text { Proportion in } \\
\text { the diet tide }{ }^{-1}\end{array}$ & $\begin{array}{l}\text { Predation } \\
\left(\text { g.ha }^{-1} \cdot d^{-1}\right)\end{array}$ & \\
\hline June & 1048.65 & 0.059 & 123.67 & 0.019 & 39.34 & 7.77 \\
\hline July & 1856.09 & 0.032 & 118.74 & 0.030 & 112.79 & 6.24 \\
\hline August & 5329.36 & 0.014 & 152.55 & 0.043 & 458.38 & 5.73 \\
\hline Sept. & 1062.91 & 0.003 & 6.12 & 0.049 & 104.12 & 5.19 \\
\hline Average & 2324.25 & & 100.27 & & 178.66 & 6.23 \\
\hline
\end{tabular}

by Cirripedia while Brachyuran crabs are common in the dry season diet. The Brachyuran crab resource is abundant in the mangrove throughout the year (Koch, 1999) and unlikely to be subject to strong monthly fluctuations in abundance. In contrast, Cirripedia are known to show high fluctuations in recruitment and survival related to changes in salinity (Sandison, 1966; Bacon, 1971). However, neither monthly changes in abundance of Cirripedia nor Brachyura were investigated during the study period in the mangrove. The IFI were significantly higher in June/July when Cirripedia dominated the diet of puffers. Assuming that Cirripedia really became less abundant in the mangrove and that Brachyura were constant, $C$. psittacus would prefer Cirripedia over Brachyura, hence prey more intensely on Brachyura only when the Cirripedia density decreases. This preference may be due to either greater forage efficiency for sessile Cirripedia or to the fact that Cirripedia are a food resource of higher quality.

The presence of teleostei in the diet of $C$. psittacus is most likely an artefact related to the fishing method. During the receding tide, the fish became physically concentrated on the upstream side of the block net. Such an artificial proximity enabled $C$. psittacus to bite off muscle tissue and scales of other fish. However, entire fish were never found in the intestines.

\subsection{Energy flow}

C. psittacus can be classified as a carnivorous second order consumer. Therefore, one of the dominant fish species of tidal mangrove channels along the north Brazilian coast lives on prey of low trophic levels. This emphasizes the conclusion of Sheaves and Molony (2000) that food chains leading from mangroves to top predators are likely to be shorter than previously thought. C. psittacus have a key function in a short intertidal mangrove food web. The energy of the mangrove detritus fuels the microbial production that is consumed by detrivorous mangrove crabs who are the prey of high-level piscine predators such as C. psittacus, but also Sciades herzbergii, Batrachoides surinamensis and some Sciaenidae. According to our current knowledge of the Caeté system, C. psittacus is the principal predator of filter feeding Cirripedia.
The mangrove productivity is, however, not exported due to offshore migration by the fish as Sheaves and Molony (2000) assumed for a system in tropical East Australia. South of the Amazon delta, where mangroves cover more than $400 \mathrm{~km}$ of continuous coastline (Lacerda et al., 2000, p. 9), other complex shallow water environments such as coral reefs or sea grass beds that could motivate offshore movements of the fish are absent. Therefore, considerable amounts of mangrove productivity, for instance taken by Brachyuran crabs and Cirripedia, are likely to remain in the mangrove ecosystem as $C$. psittacus and other dominant fish species spend their entire life in the mangrove environment (Barletta et al., 2003; Krumme et al., 2004).

\subsection{Patterns in feeding}

The diurnal neap tide submergence was a major feeding period for $C$. psittacus. Catches at neap and spring tides in intertidal mangrove creeks showed that C. psittacus is clearly diurnal at neap tides whereas at spring tide, C. psittacus forage both during the morning and the evening submergence (Krumme et al., 2004). In the study area, fiddler crabs are diurnal and cease to feed in the evening (Koch, 1999). Probably, C. psittacus rely mainly on visual cues to search for its prey. Targett (1978) also inferred that the two Sphoeroides species studied in Florida feed primarily during the day.

The overall foraging pattern of $C$. psittacus may resemble the one that Brenner and Krumme (2007) determined for another, also a visual intertidal forager in the study area, the four-eyed fish Anableps anableps: The combination of high inundation during daylight hours (spring tide-day) provided optimum foraging conditions whereas darkness and low inundation were linked to poor foraging conditions (neap tide-night); neap tide-day and spring tide-night were intermediate.

Our assumption - "no feeding at low water" - used in calculating the consumption rates is supported by the diet composition of $C$. psittacus. The specialization on Cirripedia and Brachyura suggests that C. psittacus, similar to A. anableps, primarily rely on prey located in the intertidal zone. Feeding activity is probably highest during inundation while low-water periods may be 
devoted to other activities (e.g. resting or digesting). Hence, tidally migrating $C$. psittacus may transfer mangrove productivity from the intertidal to the subtidal zone.

Given the likely low foraging activity during a nightly neap tide, our daily consumption rates of Cirripedia and Brachyura based on simply doubling the daytime consumption may be overestimates for neap tides (Table 3). However, it may provide a reasonable first estimate for average daily consumption, but a conservative estimate is likely given the increased foraging area under spring tide conditions.

C. psittacus caught in the small creek 3 had significantly emptier intestines than those of the two larger creeks 1 and 2 suggesting that smaller creeks are poorer feeding grounds for $C$. psittacus. However, C. psittacus also swim against the tide (Krumme, 2004) and possibly would have continued to forage in neighbouring creeks if they had not been blocked by the net.

\subsection{Plant-animal interaction}

In soft bottom environments of the mangrove, Cirripedia occur as part of the epibiota on permanent hard structures; mainly on stilt roots of $R$. mangle in the intertidal zone. The negligible amounts of gastropods, algae and bivalves in the diet of $C$. psittacus were likely consumed as part of the Aufwuchs (epibiota in the fouling community) associated with Cirripedia living on the stilt roots of $R$. mangle. The extensive predation of $C$. psittacus on Cirripedia suggests the existence of an important plant-animal interaction: The predation of C.psittacus decreases the coverage with Aufwuchs of mangrove stilt roots and hence increases mangrove growth as clean roots facilitate oxygen uptake by the root system (Perry, 1988). A similar mutually beneficial cleaning function is likely executed by the four-eyed fish A. anableps that primarily forage for epiphytic red algae on the stilt roots (Brenner and Krumme 2007). Likewise, Koch and Wolff (1996) assumed a cleaning function for a mangrove snail in Costa Rica. However, the positive effect of root cleaning fish on mangrove growth still awaits quantification.

\subsection{Brachyuran crabs}

The other principal food category of $C$. psittacus was semi-terrestrial Brachyuran crabs which have a considerable influence on the fluxes of organic matter and energy of the mangrove ecosystem (Koch, 1999; Koch and Wolff, 2002). Therefore, C. psittacus has a quantitatively important predatory function in the mangrove food web (Wolff et al., 2000). In the Caeté estuary, Koch and Wolff (2002) found the highest number of epibenthic species in intertidal mangrove creeks. In this mangrove habitat, $U$. maracoani, $P$. gracilis and $U$. cumulanta contributed most to the total biomass. The latter two crabs were by far the most abundant species (Koch and Wolff, 2002) and their abundance in the diet of $C$. psittacus likely reflected their numerical and weight dominance and availability in the creeks (Table 2).
The distribution of epibenthos species in the Caeté estuary follows a vertical zonation (Koch et al., 2005). Crab species that are abundant in the high intertidal zone on the mangrove plateau such as Ucides cordatus and $U$. rapax were absent from the neap tide diet of $C$. psittacus but may occur at spring tides when the mangrove forest is accessible.

Fiddler crabs stay in their burrows during the inundation period and actively forage on the mud only when the intertidal zone is exposed to air (Koch, 1999). Therefore, C. psittacus must apparently be able to detect fiddler crabs beneath the mud surface or catch individuals that are somehow active on the mud during submergence.

The relative abundance of Brachyuran crabs in the diet did not change with the fish size (Figure 1). However, especially large $C$. psittacus ate considerable amounts of Brachyuran crabs (Figures 2, 3). Targett (1978) also found that the largest puffers consumed substantial amounts of Brachyuran crabs. This is likely related to the spherical body form of puffers that allows an increase in the intestine volume closer to the power of 3 than in other fish species. The high condition factor of 3.2 highlighted this relationship. Fish with "normal" shapes have condition factors between 0.5 and 1.5 (Cinco, 1982).

\subsection{Swimming behaviour and foraging movements}

C. psittacus produce point wakes (Hanke and Bleckmann, 2004). In the study area, C. psittacus have to minutely maneuver in strong tidal currents close to the substrate in a complex mangrove environment in order to focus on both sessile and moving benthic prey. Here, point wakes may be an adaptation to prey on balanids and mangrove crabs with a minimum of turbulent disturbance as behavioral responses to chemical and visual cues are involved in predator avoidance of fiddler crabs (Chiussi and Diaz, 2002) and the mangrove tree crab Aratus pisonii (Chiussi, 2003).

In contrast to other mangrove fish, foraging C. psittacus often swim close to the water surface. In the center of the larger mangrove channels, they patrol for prey especially at the ebb tide by maintaining a position while swimming against the current (Krumme and Saint-Paul, 2003). In the shallower mangrove creeks $C$. psittacus maneuver close to the creek levees. At spring tides, juvenile $C$. psittacus can be observed on the flooded mangrove plateau in water less than $0.1 \mathrm{~m}$ deep foraging for Brachyuran crabs and Insecta (pers. obs.). During these near-surface excursions, the warning coloration in the dorsal aspect may serve against terrestrial predators such as egrets (Casmerodius albus, Egretta thula), the raccoon Procyon cancrivorus or the ape Cebus apella. Rapid inflation of the abdominal cavity may serve against the nocturnal fishing bat Noctilio leporinus but is primarily a defense against piscine predators.

\subsection{Potential resource}

The $C$. psittacus resource in north Brazil is currently unused due to the known toxicity of the fish. However, considering the current labor situation of the "mangrove 
civilizations" in the region (Glaser, 2003), two possible income alternatives using $C$. psittacus may emerge: i) sustainable catch and filet processing for exports to east Asia; and ii) developing certified aquaculture methods for sustainable breeding of puffers for the aquarium trade (Duncan and de la Parra, 2002; Gasparini et al., 2005).

Acknowledgments - We are grateful to A. Barletta-Bergan and M. Barletta, and the fishermen Walmiro and André for support during the sampling. We would like to thank M. Taylor and T. Giarrizzo for their comments on the manuscript. This work resulted from the cooperation between the Center for Tropical Marine Ecology (ZMT), Bremen, Germany, and the Univ. Federal do Pará (UFPa), Belém, Brazil, under the Governmental Agreement on Cooperation in the Field of Scientific Research and Technological Development between Germany and Brazil financed by the German Ministry for Education, Science, Research and Technology (BMBF) [Project number: 03F0253A, Mangrove Dynamics and Management - MADAM], and the Conselho Nacional de Pesquisa e Tecnologia (CNPq) [MADAM contribution 94].

\section{References}

ABBOTT, RT., 1974. American seashells. New York. Van Nostrand Reinhold Co.

AL-HUSSAINI, AH., 1947. The feeding habits and the morphology of the alimentary tract of some teleosts living in the neighbourhood of the Marine Biological Station, Ghardaqa, Red Sea. Publ. Mar. Biol. Stat. Ghardaqa, vol. 5, p. 1-61.

BACON, PR., 1971. The maintenance of a resident population of Balanus eburneus (Gould) in relation to salinity fluctuations in a Trinidad mangrove swamp. J. Exp. Mar. Biol. Ecol., vol. 6, no. 3, p. 187-198.

BARLETTA, M., BARLETTA-BERGAN, A. and SAINT-PAUL, U., 1998. Description of the fisheries structure in the mangrove-dominated region of Bragança (state of Pará, North Brasil). Ecotropica, vol. 4, p. 41-53.

BARLETTA, M., BARLETTA-BERGAN, A., SAINT-PAUL, U. and HUBOLD, G., 2003. Seasonal changes in density, biomass, and diversity of estuarine fishes in tidal mangrove creeks of the lower Caeté Estuary (northern Brazilian coast, east Amazon). Mar. Ecol. Prog. Ser, vol. 256, p. 217-228.

BARLETTA-BERGAN, A., 1999. Structure and seasonal dynamics of larval and juvenile fish in the mangrove-fringed estuary of the Rio Caeté in North Brazil. (PhD thesis) - Zentrum für Marine Tropenökologie, Bremen, ZMT contribution 8, 220p.

BARLETTA-BERGAN, A., BARLETTA, M. and SAINT-PAUL, U., 2002. Community structure and temporal variability of ichthyoplankton in north Brazilian mangrove creeks. J. Fish Biol., vol. 61, Suppl. A, p. 33-51.

BARTHEM, RB., 1985. Ocorrencia, distribuição e biologia dos peixes da Baia de Marajo, Estuario Amazonico. Bol. Mus. Para. Emilio Goeldi Zool., vol. 2, no. 1, p. 49-69.

BELL, JD., POLLARD, DA., BURCHMORE, JJ., PEASE, BC. AND MIDDLETON, MJ., 1984. Structure of a fish community in a temperate tidal mangrove creek in Botany Bay, New South Wales. Austral. J. Mar. Freshwater Res., vol. 35, no. 1, p. 33-46.
BEUMER, JP., 1978. Feeding ecology of four fishes from a mangrove creek in north Queensland, Australia. J. Fish Biol., vol. 12 , no. 5 , p. $475-490$.

BREDER, CM JR. and CLARK, E., 1947. A contribution to the visceral anatomy, development, and relationships of the Plectognathi. Bull. Am. Mus. Nat. Hist., vol. 88, p. 287-320.

BRENNER, M., BUCK, BH., CORDES, S., DIETRICH, L., JACOB, U., MINTENBECK, K., SCHRÖDER, A., BREY, T., KNUST R. and ARNTZ, WE., 2001. The role of iceberg scours in niche separation within the Antartic fish genus Trematomus. Polar Biol., vol. 24, p. 502-507.

BRENNER, M. and KRUMME, U., 2007. Tidal migration and patterns in feeding of the four-eyed fish Anableps anableps L. in a north Brazilian mangrove. J. Fish Biol., vol. 70, p. 406-427.

BREWER, DT., BLABER, SJM. and SALINI, JP., 1991. Predation on penaeid prawns by fishes in Albatross bay, Gulf of Carpentaria. Mar. Biol., vol. 109, p. 231-240.

CASTRO, ACL., 2001. Diversidade da assembléia de peixes em igarapés do estuário do Rio Paciência (MA - Brasil). Atlântica, vol. 23, p. 39-47.

CERVIGÓN, F., CIPRIANI, R., FISCHER, W., GARIBALDI, L., HENDRICKX, M., LEMUS, AJ., MÁRQUEZ, R., POUTIERS, JM., ROBAINA, G. and RODRIGUEZ, B., 1992. FAO species identification sheets for fishery purposes. Field guide to the commercial marine and brackishwater species of the northern coast of South America. FAO, Rome, 513p.

CHACE, FA. and HOBBS, HH., 1969. The freshwater and terrestrial decapod crustaceans of the West Indies with special reference to Dominica. United States National Museum Bulletin 292. Washington D.C., Smithsonian Institution Press, 243p.

CHIUSSI, R. and DIAZ, H., 2002. Orientation of the fiddler crab, Uca cumulanta: responses to chemical and visual cues. $J$. Chem. Ecol., vol. 28, no. 9, p. 1787-1796.

CHIUSSI, R., 2003. Orientation and shape discrimination in juveniles and adults of the mangrove crab Aratus pisonii (H. Milne Edwards, 1837): Effect of predator and chemical cues. Mar. Freshwater Behav. Physiol., vol. 36, no. 1, p. 41-50.

CINCO, E., 1982. Length-weight relationships of fishes. In: PAULY, D. and MINES, AN., (Eds.), Small-scale fisheries of San Miguel Bay, Philippines: Biology and stock assessment. ICLARM Technical Report 7. p. 34-37.

CLARKE, KR. and WARWICK, RM., 1994. Changes in marine communities: An approach to statistical analysis and interpretation. Plymouth Marine Laboratory. Natural Environment Research Council, U.K.

COSTELLO, MJ., 1990. Predator feeding strategy and prey importance: a new graphical analysis. J. Fish Biol., vol. 36, p. 261-263.

D’INCAO, F., 1995. Taxonomia e padrões distribucionais e ecológicas dos Dendrobranchiata (Crustacea: Decapoda) do litoral brasilerio. $\mathrm{PhD}$ thesis, Universidade Federal de Parana, Curitiba, p. 95-135.

DUNCAN, N. and DE LA PARRA, IA., 2002. Marine fish specialists focus on puffer fish. World Aquaculture, vol. 33, no. 3, p. 34-37.

DUNCAN, RS. and SZELISTOWSKI, WA., 1998. Influence of puffer predation on vertical distribution of mangrove littorinids 
in the Gulf of Nicoya, Costa Rica. Oecologia, vol. 117, no. 3, p. $433-442$.

FIEDLER, K., 1991. Lehrbuch der speziellen Zoologie. Band II: Wirbeltiere, Teil 2: Fische, Gustav Fischer Verlag, Jena, 498p.

GASPARINI, LJ., FLOETER, SR., FERREIRA, CEL. and SAZIMA, I., 2005. Marine ornamental trade in Brazil. Biodiv. Conserv., vol. 14, no. 12, p. 2883-2899.

GLASER,M., 2003. Interrelations between mangrove ecosystem, local economy and social sustainability in Caeté estuary, north Brazil. Wetlands Ecol. Manag., vol. 11, p. 265-272.

HANKE, W. and BLECKMANN, H., 2004. The hydrodynamic trails of Lepomis gibbosus (Centrarchidae), Colomesus psittacus (Tetraodontidae) and Thysochromis ansorgii (Cichlidae) investigated with scanning particle image velocimetry. J. Exp. Biol., vol. 207, p. 1585-1596.

HAYWARD, PJ. and RYLAND, JS., 1995. Handbook of the marine fauna of North-West Europe. Oxford University Press, Oxford, 800p.

HINDELL, JS. and JENKINS, GP., 2004. Spatial and temporal variability in the assemblage structure of fishes associated with mangroves (Avicennia marina) and intertidal mudflats in temperate Australian embayments. Mar. Biol., vol. 144, p. 385-395.

HUREAU, JC., 1970. Biologie comparée de quelques poissons antartiques (Nothotheniidae). Bull. Inst. Océanogr. Monaco, vol. 68 , no. 1391,244 p.

KAESTNER, A. 1963. Lehrbuch der speziellen Zoologie. Teil 1: Wirbellose (2). Jena: VEB Gustav Fischer Verlag, 1423p.

KEITH, P., LE BAIL PY. and PLANQUETTE, P., 2000. Atlas of French Guiana freshwater fishes, t. 2, fasc.1: Batrachoidiformes, Mugiliformes, Beloniformes, Cyprinodontiformes, Synbranchiformes, Perciformes, Pleuronectiformes, Tetraodontiformes. Publications scientifiques du M.N.H.N, Paris, Patrimoines Naturels, vol. 43, no. 1, 286p.

KJERFVE, B. and LACERDA, LD., 1993. Mangroves of Brazil. In: LACERDA, LD., (Ed.), Mangrove ecosystems. Technical reports ITTO TS, vol. 13, no. 2, p. 245-272.

KOCH, V. and WOLFF, M., 1996. The mangrove snail Thais kiosquiformis Duclos: A case of life history adaptation to an extreme environment. J. Shellfish Res., vol. 15, no. 2, p. $421-432$.

-, 2002. Energy budget and ecological role of mangrove epibenthos in the Caeté estuary, North Brazil. Mar. Ecol. Prog. Ser., vol. 228, p. 119-130.

KOCH, V., 1999. Epibenthic production and energy flow in the Caeté mangrove estuary, North Brazil. $\mathrm{PhD}$ thesis, Zentrum für Marine Tropenökologie, Bremen, ZMT contribution 6, 97p.

KOCH, V., WOLFF, M. and DIELE, K., 2005. Comparative population dynamics of four fiddler crabs (Ocypodidae, Genus Uca) from a North Brazilian mangrove ecosystem. Mar. Ecol. Prog. Ser., vol. 291, p. 177-188.

KREBS, JR. and DAVIS, NB., 1993. An introduction to behavioural ecology. Third edition, Blackwell Scientific Publications, Oxford.

KRUMME, U. and SAINT-PAUL, U., 2003. Observations of fish migration in a macrotidal mangrove channel in Northern
Brazil using a 200-kHz split-beam sonar. Aquat. Living Resour., vol. 16 , no. 3 , p. $175-184$.

KRUMME, U., 2004. Patterns in tidal migration of fish in a Brazilian mangrove channel as revealed by a split-beam echosounder. Fish. Res., vol. 70, no. 1, p. 1-15.

KRUMME, U., SAINT-PAUL, U. and ROSENTHAL, H., 2004. Tidal and diel changes in the structure of a nekton assemblage in small intertidal mangrove creeks in northern Brazil. Aquat. Living Resour, vol. 17, p. 215-229.

LACERDA, LD., CONDE, JE., KJERFVE, B., ALRAVEZLEAN, R., ALARCON, C. and POLANIA, J., 2000. American mangroves. In: LACERDA, LD., (Ed.), Mangrove ecosystems: function and management, Springer, Berlin, p. 1-62.

LAGUNA, J., 1985. Systematics, ecology and distribution of barnacles (Cirripedia: Thoracica) of Panama, including an analysis of provincialism in the tropical eastern Pacific. (MSc thesis) - University of California, San Diego, 231p.

ODUM, WE., 1970. Utilization of the direct grazing and plant detritus food chains by the striped mullet Mugil cephalus. In: STEELE, JH., (Ed.). Marine food chains, Oliver and Boyd, Edinburgh, p. 222-240.

PERRY, DM., 1988. Effects of associated fauna on growth and productivity in the red mangrove. Ecology, vol. 69, no. 4, p. $1064-1075$

PILLAY, TVR., 1953. The food and feeding habits of the Bombay duck, Harpodon nehereus (Ham.), in the River Matlah (Bengal). Proc. Nat. Inst. Sci. India, no. 19, p. 427-435.

RIEDL, R., 1970. Fauna und Flora der Adria. Hamburg. Paul Parey Verlag.

RODRIGUEZ, G., 1980. Los crustaceos decapodos de Venezuela. Instituto Venezolano de Investigaciones Cientificas, Caracas.

SALINI, JP., BREWER, DT. and BLABER, SJM., 1998. Dietary studies on the predatory fishes of the Norman River Estuary, with particular reference to penaeid prawns. Estuar. Coast. Shelf Sci., vol. 46, no. 6, p. 837-847.

SANDISON, EE., 1966. The effect of salinity fluctuations on the life cycle of Balanus pallidus stutsburi Darwin in Lagos Harbour, Nigeria. J. Anim. Ecol., vol. 35, no. 2, p. 363-378.

SHEAVES, M. and MOLONY, B., 2000. Short-circuit in the mangrove food chain. Mar. Ecol. Prog. Ser., vol. 199, p. 97-109.

SOKAL, RR. and ROHLF, FJ., 1995, Biometry: Principles and practice of statistics in biological research, Third edition, $\mathrm{WH}$ Freeman and Company, New York, 887p.

TARGETT, TE., 1978. Food resource partitioning by the pufferfishes Spoeroides spengleri and $S$. testudineus from Biscayne Bay, Florida. Mar. Biol., vol. 49, p. 83-91.

WOLFF, M., KOCH, V. and ISAAC, V., 2000. A trophic flow model of the Caeté mangrove estuary (North Brazil) with considerations for the sustainable use of its resources. Estuar. Coast. Shelf Sci., vol. 50, no. 6, p. 789-803.

XIAO, Y., 1998. What are the units of the parameters in the power function for the length-weight relationship? Fish. Res., vol. 35 , p. 247-249. 